\title{
Isolation and Molecular Characterization of Symbiotic Bacteria Xenorhabdus Associated with Entomopathogenic Nematodes in Ghaziabad and Meerut, India
}

\author{
Swati $^{1}$, Shailendra Singh Gaurav ${ }^{2}$ \\ ${ }^{1}$ Research scholar, Dept. of Biotechnology, Mewar University NH - 79 Gangrar, Chittorgarh, Rajasthan-312901, India \\ ${ }^{2}$ Visiting professor Dept. of Biotechnology, Mewar University NH - 79 Gangrar, Chittorgarh, Rajasthan-312 901, India
}

\begin{abstract}
A survey for Entomopathogenic nematodes was conducted during 2013-2015. 100 soil samples collected from 20 different locations in Ghaziabad and Meerut, India. Eleven Entomopathogenic nematodes were isolated by insect bait method using fifth instar larvae of Galleria mellonella and 11 symbiotic bacteria were isolated from these Entomopathogenic nematodes. These were identified as three Xenorhabdus stokiae and eight Xenorhabdus indica based on molecular data.
\end{abstract}

Keyword: Symbiotic bacteria, Xenorhabdus stokiae , Xenorhabdus indica ,NBTA, Phylogenetic

\section{Introduction}

The Entomopathogenic nematode (EPN) of genus Steirnernema (Travassos, 1927) is the most intensively studied group of nematodes associated with insects. They are obligate and lethal parasites of many insect- pests making them ideal candidates for use as biological control agent against crop pest (Gaugler 2002). These nematodes are symbiotically associated with bacteria from the family Enterobacteriaceae that are pathogenic to insect. Steinernematids are associated with Xenorhabdus species (Thomas and Poiner, 1979). The third stage infective juvenile is the only free-living stage that persists in the soil in search of a susceptible arthropod host. IJs makes their entries through the natural opening (mouth, anus, spiracles) and release the symbiotic bacteria into the insect hemocoel. The mutualistic bacterium propagates and produces substances that rapidly kill the host within 24-48h. and protect the cadaver from colonization by other microorganism. The nematode initiates its development, feeding on the bacterial cells and host tissues that have been metabolized by the bacterium and has 1-3 generations, depending on host size. When food resources become depleted, new IJs either remain at the site where they were produced or disperse in search of new hosts.

Xenorhabdus bacterial genera produce phenotypic variant cell types called primary form and secondary form. The primary form is the cell type naturally associated with the nematodes whereas the secondary form can arise spontaneously when the bacterial cultures are in the stationary non-growth stage and the secondary form revert to the primary form. The primary form produces antibiotics, adsorbs certain dyes and develops large intracellular inclusion composed of crystal proteins. Secondary form only weakly produces antibiotics, dose not adsorb dyes321, and produces intracellular inclusions inefficiently. The primary form is superior to the secondary form.

\section{Material and Methods}

Isolation and identification of symbiotic bacteria Isolation of Entomopathogenic nematodes (EPNs) three Steirnernema saimkayai and eight Steirnernema thermophilum were isolated from Ghaziabad and Meerut district of western U.P, India using G.mellonella by baiting methods. Eleven native EPNs were transfer in to the surface of a filter paper in $35-\mathrm{mm}$ petri dishe and put the $G$. mellonella larvae in the dish. The dish were incubated at $28^{\circ} \mathrm{C}$ for $48 \mathrm{~h}$. The larvae cadaver were removed, rinsed in distilled water. In the sterile condition surface sterilized with $70 \%$ ethanol, flame and left to drying in a laminar.

Cadaver dissected using sterilized needles and scissor then a drop of heamolymph streaked on NBTA agar media plates ( peptone- $1.25 \mathrm{gm}$, beef extract- $0.75 \mathrm{gm}$, Agar- $3.75 \mathrm{gm}$, BTB- 0.0062gm, TTC- 0.01gm, NaCl- 1gm, Ph- 7.2, water$250 \mathrm{ml})$. NBTA agar media plates were sealed using paraflim and incubated at $28^{\circ} \mathrm{C}$ in the dark for $24 \mathrm{~h}$. Single colonies of bacteria were removed using a sterile loop and transferred to new NBTA agar plates and they were subculture continually until the single colony appear. Each single colony was selected and inoculated to a Luria broth, the flask was then placed in a shaking incubator adjusted at $200 \mathrm{rmp}$ for overnight at $28^{\circ} \mathrm{C}$.

DNA extraction, PCR and phylogenetic analysis Overnight $1 \mathrm{ml}$ of bacterial culture was transfered in to 1.5 eppendorf tube. Total genomic DNA was extracted using a DNA isolation kit ( Invitrogen Genomic DNA mini kit ). Genomic DNA gene amplification was done by a PCR gradient thermocycler using primers. The total volume of one reaction PCR mixture was $25 \mu$, containing $2.5 \mu 1$ of $10 \mathrm{x}$ buffer, $1.75 \mu \mathrm{l}$ of $50 \mathrm{mM} \mathrm{MgCl} 2,1.25 \mu \mathrm{l}$ of $10 \mathrm{mM}$ dNTPs, $1.25 \mu \mathrm{l}$ of $100 \mathrm{p}$ mole forward primer, $1.25 \mu \mathrm{l}$ of $100 \mathrm{p}$ mole reverse primer, $0.4 \mu 1$ of 5 unit Taq enzyme, $16 \mu 1$ of nuclease water and $0.5 \mu \mathrm{l}$ of genomic DNA. The PCR condition were denaturation at $95^{\circ} \mathrm{C}$ for $3 \mathrm{~min}$., followed by 


\section{International Journal of Science and Research (IJSR) \\ ISSN (Online): 2319-7064 \\ Index Copernicus Value (2013): 6.14 | Impact Factor (2014): 5.611}

35 cycles of $95^{\circ} \mathrm{C}$ for 45 sec., $58^{\circ} \mathrm{C}$ for 45 sec., $72^{\circ} \mathrm{C}$ for $2 \mathrm{~min}$. and final extension at $72^{\circ} \mathrm{C}$ for $10 \mathrm{~min}$. The DNA band was excised and extracted from the gel by using QIAGEN (min elute) Gel extraction kit. The obtained sequence of Xenorhabdus stokiae and Xenorhabdus indica were compared with sequence of Xenorhabdus stokiae and Xenorhabdus indica species available in GenBank (NCBI). The DNA Sequences were edited using BioEdit (Hall.1999) with sequences of related species and new isolates. The evolutionary relationship of the isolated with 10 species/srains for Xenorhabdus stokiae and 10 species/strains for Xenorhabdus indica were evaluated (Swofford, 2002). Phylogenetic (Neighbor joining) analysis the sequence data were done using MEGA (Tamura et.al. 2007).

\section{Results}

Bacteria were recovered from all 11 samples. Suitable quantity of purified total DNA template was extracted from the overnight bacteria culture and DNA template was yielded from each extraction. The genomic DNA from the 11 samples using the ( 5GAGTAATGTCTGGAAACTGCC $\quad 3^{\prime}, \quad$ R-5'
GTTAGCCGGTGCTGCTTCTG 3') primer were identified . The purified PCR-products were sequenced. The sequences from PCR-product were successfully obtained from all samples. Three sample in the BLAST search indicate similarity between Xenorhabdus stokiae and eight samples indicated similarities between Xenorhabdus indica. The evolutionary relationship of the isolates and other closely related species were evaluated. The phylogenetic analysis of the genomic DNA sequence data placed Xenorhabdus stokiae and Xenorhabdus indica isolates in a clade with other isolates of Xenorhabdus stokiae and Xenorhabdus indica species/strain.

\section{Acknowledgement}

I acknowledge the help and support render to me from authorities of Dr. Uma Rao, Division of Nematology, Indian Agricultural Research Institute, New Delhi and Dept. of Biotechnology, Ch. Charan Singh University, Meerut, India and Foundation for Agriculture Resources Management and Environmental Remediation ( FARMER), Ghaziabad, UP, India to complete this work.

\begin{tabular}{|l|l|l|l|l|l|}
\hline District & Village & Crop & Nematode Host & Bacteria Species & Isolates Code \\
\hline Ghaziabad & Kushliya & Cauliflower & S. saimkayai & X.stokiae & X.stokiae GHA-1 \\
\hline & & Chili & S. saimkayai & X.stokiae & X.stokiae GHA-2 \\
\hline & Dasna & Radish & S. saimkayai & X.stokiae & X.stokiae GHA-3 \\
\hline & Nabipur & Chili & S.thermophilum & X.indica & X.indica -1 \\
\hline & Satli & Cauliflower & S.thermophilum & X.indica & X.indica -2 \\
\hline Meerut & Dabarsi & Radish & S.thermophilum & X.indica & X.indica -3 \\
\hline & Shobhapur & Sugarcane & S.thermophilum & X.indica & X.indica -4 \\
\hline & & Radish & S.thermophilum & X.indica & X.indica -5 \\
\hline & Dhldi & Cauliflower & S.thermophilum & X.indica & X.indica -6 \\
\hline & & Radish & S.thermophilum & X.indica & X.indica -7 \\
\hline & Atta chidoli & Sugarcane & S.thermophilum & X.indica & X.indica -8 \\
\hline
\end{tabular}

Isolated symbiotic bacteria survey data from Ghaziabad and Meerut.

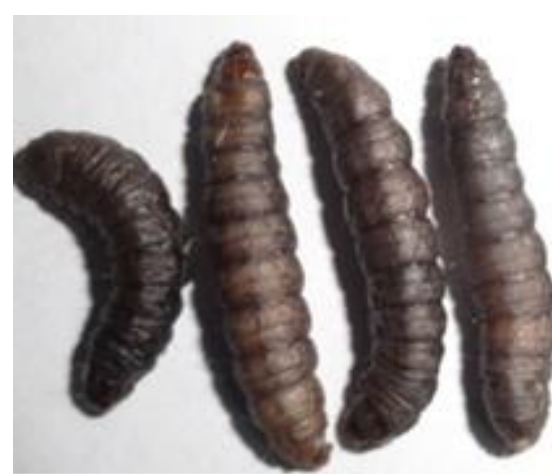

S. saimkayai cadaver



S. thermophilum cadaver 
International Journal of Science and Research (IJSR)

ISSN (Online): 2319-7064

Index Copernicus Value (2013): 6.14 | Impact Factor (2014): 5.611



Phylogenetic relationship of Steinernema species based on ITS region by Neighbour-joining method.

\section{References}

[1] Akhurst, R. J. (1980) Morphological and functional dimorphism in Xenorhabdus spp.,bacteria symbiotically associated with the insect pathogenic Neoaplectana and Heterorhabditis. Journal of General Microbiology121, 303-309.

[2] Boemar, N. (2002) Biology, taxonomy and systematic of Xenorhabdus and Photorhabdus. Pp. 35-56 in Gaugler, R. (Ed.) Entomopathogenic nematology. 402 pp. CABI Publishing, Wallinford, UK.

[3] Forst, S \& Clarke, D. (2002) Bacteria-nematode symbiosis. pp. 57-98 in Gaugler, R. R. (Ed.) Entomopathogenic nematology. 402 pp. CABI Publishing, Wallinford, UK.

[4] Woodring JL, Kaya HK (1988) Steinernematid and heterorhabditid nematodes ; a handbook of biology and techniques. Southern Cooperative Series Bulletin 331. Arkansas Argiculturral Experiment Station, Arkansas.

[5] Joyce, S.A., BRUNELL,A.M \& POWERS, T.O.(1994) Characterization of Heterorhabditis isolates by PCR amplification of segments of mtDNA and rDNA genes. J. Nematol., 26: 260-270

[6] David I. Shapiro-ILAN (2006); Effect of soil moisture and surfactant on Entomopathogenic nematode suppression of pecan weevil, Curculio caryae, journal of Nematology 38 (4); 474-482.

[7] Arun K . Yadav. Lalramliana (2012) Efficacy of indigenous Entomopathogenic nematodes from Meghalaya, India against the larvae of taro leaf beetale, Aplosonyx chalybaeus (Hope). J Parasit Dis.

[8] Boemare, N. (2002) Biology, Taxonomy and Systematics of Photorhabdus and Xenorhabdus. In:
Entomopathogenic Nematology, (Ed R. Gaugler). CABI Publishing, Wallinford UK, pp 35-56.

[9] Georgis R (1992): Present and future prospects for Entomopathogenic nematode products. Biocontrol Sci Techn 2: 83-89.

[10] Kaya HK, Gaugler R (1993): Entomopathogenic Nematodes. An Rev E ntomol 38: 181-206.

[11] Akhurst RJ (1990). Safety to invertebrate non-target organisms of nematodes used for biocontrol.In: Safety of Micobial Control Agents. (MLaird, Llacey. \& E Davidson,eds), CRC Press,Boca Raton, pp. 233-248.

[12] Griffin CT (1993). Temperature responses of Entomopathogenic nematodes for the success of biological control programs. In: Nematodes and the Biological Control of insect Pest. (RA Bedding, RJ Akhurst \& HK Kaya, eds). CSIRO Publications, East Melbourne, Australia,pp.101-111.

[13] Mracek Z, Becvar S, Rezac P, Kindlmann P\& Webster JM (1997). Canadian (Nematoda) isolates and their infectivity, under cold conditions, to greater wax moth (Galleria mellonella) larvae. Biol Control, 8, 160-164.

[14] Mracek Z \& Webster JM (1993). Survey of Heterorhabditidae and Steinernematidae (Rhabditidae: Nematoda) in Western CANADA. J. Nematol, 25, 710717

[15] Hall TA (1999). BioEdit: a user-friendly biological sequence alignment editor and analysis program for Windows 95/98/NT. Nucleic Acids Symposium Series 41:95-98.

[16] Swofford,DL (2002) PAUP/Phylogenetic Analysis Using Pasimony (and other methods). Sunderland, MA.USA; Sinauer Associates. 